\title{
Drug Induced Oral Mucosal Pigmentation- A Review
}

\section{Sumit Bhateja *, Ankita Bohra and Geetika Arora}

Department of Oral Medicine Diagnosis and Radiology, Vyas Dental College and Hospital, Jodhpur, Rajasthan, India

\begin{abstract}
Medications may induce a variety of different forms of mucocutaneous pigmentation, including melanosis. This short review discusses about various drugs implicated in oral mucosal pigmentation and also pigmentation caused by heavy metal ingestion.
\end{abstract}

Keywords: Drugs; Oral pigmentation; Heavy metal

\section{Introduction}

Pigmented lesions that are of exogenous origin are usually traumatically deposited directly into the sub mucosal tissues. In some cases, the substances may be may be ingested, absorbed and distributed hematogenously to be precipitated in the connective tissues, particularly in areas subject to chronic inflammation such as gingiva [1]. In other instances these ingested substances can actually stimulate melanin production, thus precipitating color change.

The manifestation of oral pigmentation is quite variable, ranging from a focal macule to broad diffuse tumefactions [2]. The specific hue, duration, location, number, distribution, size and shape of pigmented lesion may also be of diagnostic importance.

Thus an understanding of various drugs and heavy metals that can contribute to oral and perioral pigmentation is essential for proper evaluation, diagnosis and management of the patient.

\section{Drug induced Melanosis}

The chief drugs implicated in drug induced melanosis are antimalarials including chlorquine,hydroxychloroquine, quinacrine and others [2,3]. These medications are typically used for the treatment of autoimmune diseases. Other classes of medications that induce melanosis include the phenothiazines such as chlorpromazine, oral contraceptives, cytotoxic medications such as cyclophosphamide and busulfan [4].

\section{Pathophysiology}

Possible reasons behind pathologic pigmentation are $[5,6]$

\section{Melanin accumulation.}

2. Localized accumulation of drug under layer of skin.

3. Iron accumulation throughout dermis from drug induced inflammatory changes.

4. Some special pigments synthesis due to drug influence.

\section{General Clinical Considerations}

Discontinuation of causative agent is the best treatment regarding oral drug induced melanosis. Discontinuity will gradually normalize the hypermelanotic pigmentation. Along with it, general dental prophylactic measures should be followed like proper oral hygiene maintainence and regular dental visits $[7,8]$ (Table 1).

\section{Heavy Metal Pigmentation}

Increased levels of heavy metals (e.g., lead, bismuth, mercury, silver, arsenic and gold) in the blood represent a known cause of oral mucosal discolouration.

\section{Causes}

1. In adults, the most common cause for such increased levels is occupational exposure to heavy metal vapours.

2 . Treatment with drugs containing heavy metals, such as arsenicals for syphilis, was a common cause in the past.

3. In children, possible sources of exposure include leadcontaminated water or paint and mercury or silver-containing drugs.

These ingested pigments tend to extravasate from vessels in foci of increased capillary permeability such as inflamed tissues. Thus, in the oral cavity, the pigmentation is usually found along the free marginal gingiva, where it dramatically outlines the gingival cuff. This metallic line has a gray to black appearance. The importance of oral mucosal pigmentation associated with heavy metals lies primarily in the recognition and treatment of the underlying cause to avoid severe systemic toxic effects. The heavy metals may be associated with systemic symptoms of toxicity, including behavioral changes, neurologic disorders, and intestinal pain. This condition is now rarely seen $[9,10]$.

\section{Conclusion}

Drug induced melanin pigmentation may show a varying degree

\begin{tabular}{|c|}
\hline DRUGS CAUSING ORAL \& PERIORAL PIGMENTATION \\
\hline Amiodarone \\
\hline Amodioquine \\
\hline Aziodothymidine \\
\hline Bleomycin \\
\hline Chloroquine \\
\hline Chlorpromazine \\
Clofazamine \\
\hline Gold \\
\hline Hydroxychloroquine \\
\hline Hydroxyurea \\
\hline Imipramine \\
\hline Ketoconazole \\
Mepacrine
\end{tabular}

Table 1: Drugs causing oral and perioral pigmentation.

*Corresponding author: Sumit Bhateja, 05072, ats Advantage, Ahinsa khand-I, Indirapuram Ghaziabad -201014, Uttar Pradesh, India, Tel: 91-8764232105; E-mail: bhateja.sumit@gmail.com

Received April 20, 2015; Accepted July 09, 2015; Published July 19, 2015

Citation: Bhateja S, Bohra A, Arora G (2015) Drug Induced Oral Mucosal Pigmentation- A Review. Pigmentary Disorders 2: 198. doi:10.4172/23760427.1000198

Copyright: $\odot 2015$ Bhateja S, et al. This is an open-access article distributed under the terms of the Creative Commons Attribution License, which permits unrestricted use, distribution, and reproduction in any medium, provided the original author and source are credited. 
of presentations. Many pigmented lesions can be clinically diagnosed based on history and clinical features. These pigmentations can be caused by both systemic and topical medications. Complete local and systemic assessment of the patient should be performed prior to diagnosing these entities.

\section{References}

1. Wright JM (1984) Oral manifestations of drug reactions. Dent Clin North Am 28: $529-543$

2. Porter SR, Scully C (2000) Adverse drug reactions in mouth. Clin Dermatology18: 222-230.

3. Lanier VC Jr, Pickrell KL, Georgiade NG (1976) Congenital giant nevi: clinical and pathological considerations. Plast Reconstr Surg 58: 48-54.

4. Marghoob AA1, Schoenbach SP, Kopf AW, Orlow SJ, Nossa R, et al. (1996) Large congenital melanocytic nevi and the risk for the development of malignant melanoma. A prospective study. Arch Dermatol 132: 170-175.
5. Margoob AA, Schoenbach SP, Kopf AW, Orlow SJ, Nossa R, et al (1995) Pathophysiology of drug induced melanin pigmentation \& the risk of developing malignancy: a review of the world literature. J Invest Dermatol 104: 563-565.

6. Pack GT, Davis J (1961) Nevus giganticus pigmentosus with malignant transformation. Surgery 49: 347-354.

7. Padilla RS, McConnell TS, Gribble JT, Smoot C (1988) Malignant melanoma arising in a giant congenital melanocytic nevus. A case report with cytogenetic and histopathologic analyses. Cancer 62: 2589-2594.

8. Quaba AA, Wallace AF (1986) The incidence of malignant melanoma (0 to 15 years of age) arising in "large" congenital nevocellular nevi. Plast Reconstr Surg 78: 174-181.

9. Richardson SK, Tannous ZS, Mihm MC Jr (2002) Congenital and infantile melanoma: review of the literature and report of an uncommon variant, pigmentsynthesizing melanoma. J Am Acad Dermatol 47: 77-90.

10. Ruiz-Maldonado R, Tamayo L, Laterza AM, Durán C (1992) Giant pigmented nevi: clinical, histopathologic, and therapeutic considerations. J Pediatr 120: 906-911. 